\title{
USE OF MOLECULAR APPROACH TO VERIFY THE INFLUENCE OF A EUTROPHIC LAGOON IN THE NEARBY OCEAN'S BACTERIOPLANKTON COMMUNITIES
}

\author{
Rodrigo Gouvêa Taketani ${ }^{1}$; Fábio Vieira Araujo ${ }^{2}$; Margaretha Denise Maria van Weerelt ${ }^{3}$; \\ Maria Leonisa Sanchez-Nunez ${ }^{3}$; Erick Aniszewski ${ }^{1}$; Alexandre Soares Rosado ${ }^{1 *}$ \\ ${ }^{1}$ Laboratório de Ecologia Microbiana Molecular, Instituto de Microbiologia, Universidade Federal do Rio de Janeiro, \\ Rio de Janeiro, RJ, Brasil. ${ }^{2}$ Departamento de Ciências, Faculdade de Formação de Professores, Universidade Estadual do \\ Rio de Janeiro, Rio de Janeiro, RJ, Brasil. ${ }^{3}$ Laboratório de Microbiologia Marinha, Instituto de Biologia, \\ Universidade Federal do Rio de Janeiro, Rio de Janeiro, RJ, Brasil.
}

This paper corresponds to an "extended abstract" selected for oral presentation in the $22^{\text {nd }}$ Brazilian Congress of Microbiology, held in Florianópolis, SC, Brazil, in November 17-20, 2003

\begin{abstract}
Rodrigo de Freitas lagoon is an eutrophic aquatic environment. The waters from the lagoon are released to the sea at Ipanema and Leblon beaches, through Jardim de Alah channel. In this work, the influence of these waters on the bacterial communities of these beaches was investigated. Eleven sampling stations were set between the lagoon and the beaches, and the samples were analyzed by molecular and microbiological parameters. PCRDGGE of the DNA extracted from the samples was performed using rpoB primers. Preliminary results indicate that all used approaches could reveal the influence of the lagoon on the beaches bacterial communities.
\end{abstract}

Key words: DGGE, diversity, bacterioplankton, eutrophic lagoon.

\section{INTRODUCTION}

The subject of prokaryotic biodiversity in the sea has received new and substantial attention with the development of molecular techniques to describe and identify the microbial components of natural communities. PCR amplification and the cloning of diagnostic molecules permit extensive studies of the microbial diversity of ecosystems without the bias imposed by pure-culture techniques (1).

This study aims to verify the influence of an eutrophic lagoon (Rodrigo de Freitas) on the nearby oceanic beaches (Ipanema and Leblon) (Rio de Janeiro, Brazil), using molecular techniques (PCR-DGGE). The results presented here are preliminary.

\section{MATERIALS AND METHODS}

Sub-superficial water samples of eleven sampling points distributed along Rodrigo de Freitas lagoon (4 points: \#1, \#2, \#3 and \#4), Jardim de Alah channel ( 2 points: \#5 and \#6) and Ipanema (2 points: \#10 and \#11) and Leblon (3 points: \#7, \#8 and \#9) beaches were acquired with a $3 \mathrm{~L}$ Van-Dorn bottle. Sub-samples were separated for molecular and microbiological analysis.

Bacterial counting was determined by epifluorescence (3) and total coliforms(TC) and fecal coliforms (FC) by MPN (2).

Triplicates of $300 \mathrm{~mL}$ water samples were pre-filtered in $3.0^{1 / 4 \mathrm{~m}}$ pore membranes, and then filtered in $0.2^{1 / 4} / \mathrm{m}$ membranes. Half of a membrane was cut and DNA was extracted with FastDNA@ SpinKit (Bio101, California, USA). PCR-DGGE using primers rpoB $1698 \mathrm{~F}$ and rpoB 2041R were performed as described by Peixoto et al. (4). An UPGMA cluster analysis using Dice's coefficient was constructed using the DGGE data.

\section{RESULTS AND DISCUSSION}

The Rodrigo de Freitas lagoon is known by its high level of waste water pollution (eutrophic environment). The consequence

*Corresponding author. Mailing address: Instituto de Microbiologia. Universidade Federal do Rio de Janeiro. Prof. Paulo de Góes. CCS - Bloco I - Lab 045. Ilha do Fundão. 21941-590, Rio de Janeiro, RJ, Brasil. E-mail: asrosado@micro.ufrj.br 
of that is reflected in the large cell density in these samples observed through epifluorescence microscopy. The values seen for TC and FC were greater than those acceptable for primary contact. These results also show that much of the nutrients may come from domestic waste (Fig. 1).

The values for samples collected on the beach were lower than those of the lagoon samples, and they decrease with the increase of the distance from the channel.

The dendrogram constructed from the DGGE banding pattern shows two separate groups: one formed by the stations in the lagoon and channel, and the other by the ones on the beach (Fig. 2). The influence of the eutrophic waters of the lagoon may be observed through the formation of a subgroup

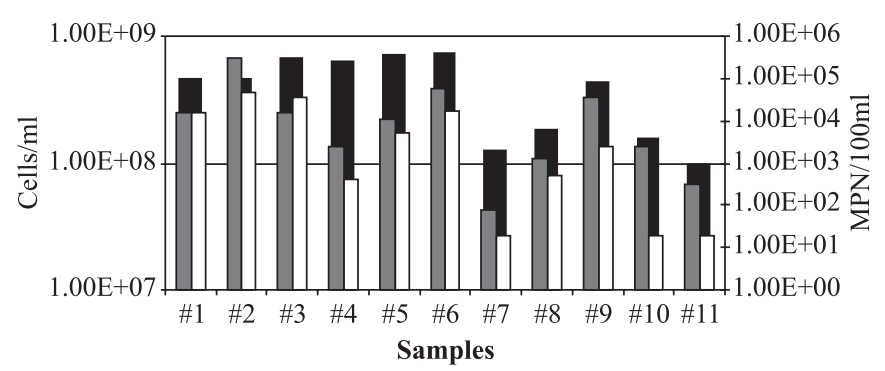

Figure 1. Bacterial cell counting by epifluorescence microscopy ( $\square$ ); fecal coliforms ( $\square$ ); total coliforms ( $\square$ ).

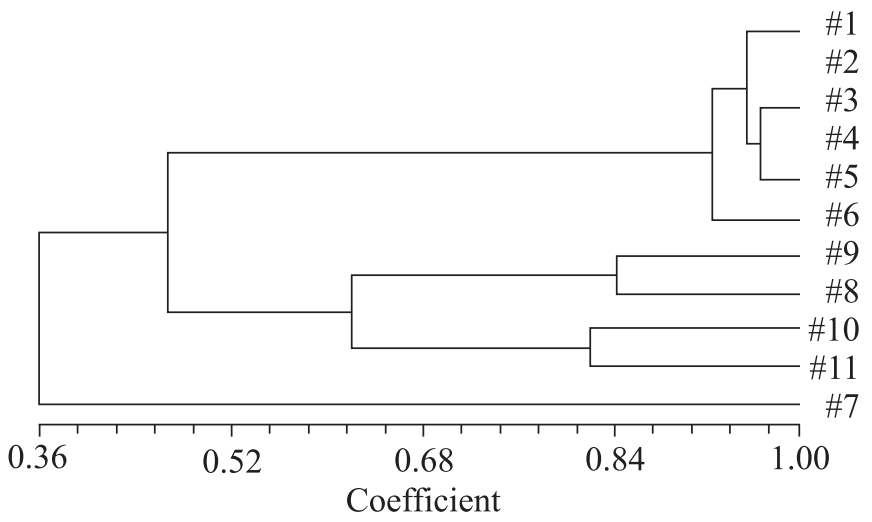

Figure 2. Dendrogram (UPGMA) of PCR-DGGE analysis with Dices distance matrix. See M\&M section for sampling points numbers. of samples collected near the channel (sampling points \#8 and \#9). This group shows more similarity with the samples from the lagoon-channel group than the other samples collected farther from the channel. Further analysis shall be made to investigate the relationship between the collected data.

\section{RESUMO}

\section{Uso de metodologia molecular para verificar a influência de uma lagoa eutrófica na comunidade bacterioplanctônica do oceano adjacente}

A lagoa Rodrigo de Freitas é um ambiente aquático eutrofizado, cujas águas são lançadas ao mar nas praias de Ipanema e Leblon através do canal do Jardim de Alah. Nesse trabalho, foi estudada a influência desse aporte na comunidade bacteriana dessas praias. Para isso coletou-se água de onze estações distribuídas entre a lagoa e as praias. Essas amostras foram analisadas quanto a parâmetros moleculares e microbiológicos. Foi realizado também PCR-DGGE utilizandose iniciadores para o gene rpo $\mathrm{B}$, a partir de DNA extraído das amostras de água coletadas. Resultados preliminares mostram que a influência da lagoa na comunidade bacteriana das praias pode ser verificada por todas as abordagens.

Palavras-chave: DGGE, diversidade, bacterioplancton, lagoa eutrófica.

\section{REFERENCES}

1. Acinas, S.G.; Antón, J.; Rodríguez-Valera. Diversity of Free-Living and Attached Bacteria in Offshore Western Mediterranean Waters as Depicted by Analysis of Genes Encoding 16S rRNA. Appl. Environ. Microbiol., 65:514-522, 1999.

2. American Public Health Association - APHA. Standart methods for examination of water and wastewater. $20^{\text {th }}$ ed. Greenberg, A.E., Clesceri, L.S.; Eaton, A. D. APHA/AWWA/WEF. Washington, 1998.

3. Bloem, J. Fluorescent staining of microbes for total direct counts. In: Akkermans, A.D.L.; van Elsas, J.D.; De Bruijn, F.J. (eds). Molecular Microbial Ecology Manual. Kluwer Academic Publishers, London, 1995, p.4.1.8.

4. Peixoto, R.S.; Coutinho H.L.C.; Rumjanek, N.G.; Macrae, A.; Rosado A.S. Use of $r p o B$ and $16 S r R N A$ genes to analyse bacterial diversity of a tropical soil using PCR and DGGE. Lett. Appl. Microbiol., 35(4):316-20, 2002.

5. Strickland, J.D.H.; Parsons, T.R. A practical handbook of seawater analysis. Fisheries research board of Canada, Ottawa, 1972, p.310. 